\title{
The construction of word meaning in a multicultural classroom. Mediational tools in peer collaboration during mathematics lessons
}

\author{
Ed Elbers
}

Mariëtte de Haan

Utrecht University, The Netherlands

In this article, we examine the construction of word meaning by students during collaborative activities in a multicultural classroom at a Dutch primary school. The analysis is based on recordings of student talk in small groups of four or five students during mathematics lessons. Difficulties with specific terms and expressions frequently arose during group work. Students could easily ask each other about the meaning of difficult words as a part of the collaborative activities they were accustomed to. In the groups with both Dutch and minority children, the minority students addressed their Dutch classmates as language experts. Conversations about language difficulties also occurred in the groups with only minority students. The conversations about word meaning revealed four patterns: (1) ignoring a question about the meaning of a word, (2) showing the meaning using gestures, (3) explaining, or (4) discussing word meaning. In none of the cases were the language problems solved by referring to the everyday meaning of the word. Instead, the conversations focussed directly on the specialised meaning which the word had in the context of the mathematics lesson. This means that the children used the mathematical discourse as a mediational tool for constructing a mathematical meaning of the words.

\section{Introduction}

The Netherlands has an increasing migrant population with Moroccans, Turks, Surinamese and people from the Dutch Antilles as the largest minority groups. Dutch primary schools, in 2003, had a population of, on average, $15 \%$ minority students. The minority population is concentrated in the larger cities, especially in Amsterdam, Rotterdam, The

The research reported in this article was funded by the Programming Council for Educational Research (PROO) of the Netherlands Organization for Scientific Research (NOW). 
Hague and Utrecht. In these cities, schools have an average of between $38 \%$ and $57 \%$ minority students (CBS, 2004). Minorities are concentrated in certain areas of the cities, and therefore some primary schools have a percentage of minority students as high as $80 \%$ or even $90 \%$.

The language of instruction in schools in the Netherlands is Dutch. It is well documented that children who do not belong to the language majority, i.e., children who speak a different language at home, encounter difficulties at school. Dutch researchers have measured the Dutch language competence of primary school children. At the end of primary school students with Turkish, Moroccan and Antillean backgrounds are on average about two years behind their native Dutch classmates. Surinamese students do slightly better. Although the achievements of minority students in school subjects, such as mathematics, have improved considerably over the past few years, their lack of fluency in speaking, reading and writing Dutch is a cause for concern (Dagevos, Gijsberts, \& Van Praag, 2003; Tesser \& Iedema, 2001).

In this contribution we study peer conversations during mathematics lessons, and, in particular, the way students deal with language problems that originate from minority students' unfamiliarity with specific Dutch words and expressions. Mathematics teaching in the Netherlands has been influenced by the Realistic Mathematics Education (RME) of Hans Freudenthal (1991). This form of mathematics teaching is a reaction to more traditional approaches which demanded students to apply algorithms introduced by the teacher. In realistic mathematics, students are encouraged to construct mathematical knowledge and insights themselves. To stimulate students' own constructions and productions, the textbooks present everyday ('realistic') situations that are motivating and which can be used by the students to develop and deepen their understanding. RME is an attempt to provide links between a representation of an everyday problem situation and a representation of mathematical relations (cf. Nunes, Schliemann, \& Caraher, 1993). Textbooks present many assignments which refer to recognisable situations and use terms and expressions from everyday life (Figure 1 is an example). Doing mathematics presupposes a good knowledge of Dutch language and culture.

A recent Dutch study by Van den Boer (2003) in secondary schools documents the difficulties of minority students when they have to solve math assignments they do not understand. Their lack of knowledge of Dutch words and expressions sometimes prevents them from doing the assignment. Van den Boer showed that minority students read the math assignments only superficially or even incompletely (in this respect they are probably not different from Dutch students!). They avoided language problems by omitting difficult or unfamiliar terms and by clever guessing. In interviews, minority students told Van den Boer that they are aware that they sometimes do not understand an assignment and that they have resigned themselves to that fact. They did not think it particularly important. They were of the opinion that they are able to do the assignment even if they do not fully understand it.

A second finding of Van den Boer's study is that the meaning of words was rarely a subject of instruction during mathematics lessons. Students did not ask questions about unfamiliar words and teachers did not check whether students had understood the text of the math problems. Both the teachers and the textbooks appear to assume that students have no problems with the words and expressions used in the assignments. This assumption is clearly wrong. However, Van den Boer demonstrated that teachers in her study often discouraged the asking of questions and gave students only limited opportunity to speak out. Teachers told her that they wanted to stick to their own plan for the lesson. Van den Boer found that when a student's question did not fit well into the structure of the lesson, teachers said it was irrelevant or belonged to a topic to which they would return later.

The classrooms observed by Van den Boer were characterized by teacher fronted instruction. In the present article, we will give an account of our observations at a school in which this form of instruction was an exception, since students were engaged in peer collaboration during most of the lessons. Part of students' collaborative activities, as we will show, was the assistance they gave each other to solve problems with the language of instruction. 
Language learning is a social and collaborative enterprise. Recent approaches to foreign language learning underscore that interaction and negotiation of meaning are an essential part of acquiring an active command of a new language, including the acquisition of its vocabulary (Long, 1996; Coady, 1997; Van den Brande, 1997; De la Fuente, 2002). Learning a foreign language should preferably occur in collaborative dialogues in which interlocutors work at creating joint understanding. These dialogues, according to Swain (2000), serve two functions. In producing their share in conversations, foreign language students have to create linguistic form and meaning; the mental effort needed for doing this demands a more flexible and complete use of their language skills than the passive reception of input. In addition, actively contributing to a conversation leads to utterances, which become objects of reflection either by the interlocutor whose reaction is a form of feedback or by the first speaker who discovers the gaps in his or her language skills. The dialogue is a social tool that mediates the learning of the language. What has been jointly constructed in the dialogue facilitates the appropriation of linguistic and pragmatic knowledge, as part of an internalisation process, in which "internal mental activity has its origins in external dialogic activity" (Swain, 2000, p. 112).

Researchers of interaction involving foreign language learning have mostly used artificial settings, for instance, they form pairs of native and non-native speakers who have to discuss a particular task (Porter, 1986, and Mackey, Oliver, \& Leeman, 2003, are just two examples). Moreover, studies tend to concentrate on grammatical, conversational and vocabulary skills of a general nature, rather than analyse conversations in the context of learning specific content and studying the influence of subject matter on the conversations (cf. the criticism by Lee \& Fradd, 1996). The limitations of these studies could be overcome by making observations of discussions between (native and non-native) students in the context of content learning in the classroom. Moschkovich's (2002) article prepares the way for analysing natural observations in the mathematics classroom. She discusses the role of language in learning mathematics in bilingual (English/Spanish) classrooms. Moschkovich is critical of some researchers' concentration on vocabulary difficulties in mathematics lessons, since, she argues, current views on learning mathematics focus on other aims than the use of the right vocabulary. These views emphasise students' participation in discussions and their presentation of arguments. For participating successfully in mathematics lessons, students can use various means, even if they are hampered by an incomplete vocabulary in the language of instruction. Moschkovisch shows that students, in presenting their mathematical argument, apply a variety of tools, such as gestures, every day experiences, code switching and representations. Vocabulary is one set of mediational tools alongside others.

We approach teaching and learning mathematics in a multicultural classroom from the perspective of Cole's (1996) theory of mediation. This theory involves a hierarchy of three levels of mediational means, originally proposed by Wartofsky (1979). The first level consists of tools and symbols directly used in the production of material and social life. The second level encompasses the conventions and norms regulating social life and interactions between people. The third level focuses on cultural representations, such as art and science, which in a fundamental way influence our perception of reality and shape our relationships with the world and with others.

In the particular classrooms involved in this study, we can recognise the three levels of mediation. The first level consists of the tools used by the students, like books and pens, but also the Dutch language, which serves as the main vehicle for communication and teaching in the classroom. On the second level, there are the social norms of collaboration, which lead to collaborative dialogues and the creation of joint understanding among students. The third level of mediation refers to the mathematical discourse that sets the stage and prescribes norms for doing and talking mathematics. It consists of the socio-mathematical norms (Yackel \& Cobb, 1996) that students learn to apply when they participate in valued mathematical practices, such as using certain kinds of representations, presenting arguments and proving conclusions.

In this article we focus on students' problems with specific words and expressions during mathematics lessons. However, we do not treat vocabulary as an isolated phenomenon. Rather, we concentrate on students' conversations about unfamiliar words in the context of 
peer collaboration and mathematical discourse. Our presentation is guided by three questions, which correspond to Cole's three levels of mediation:

1) What symbolic and material tools do students use to construct common understanding of unfamiliar words?

2) How does the social norm that students should do the assignments collaboratively influence the way students solve difficulties with words?

3) What is the influence of the mathematical discourse (and the socio-mathematical norms) on students' conversations about language problems?

\section{Method}

We have been involved for some time in a project in a multi-ethnic primary school in Utrecht, the Netherlands. The aim of this project is to analyse interaction and collaboration among students during mathematics lessons (Elbers \& Haan, 2004; Haan \& Elbers, in press). In this school, $80 \%$ of the students are from a minority background, mainly Moroccan and Turkish. Over the years, the team of teachers has developed an educational philosophy in which particular value is attached to collaboration. The teachers have been trained to stimulate and encourage collaboration among the students. Part of the lessons consists of students working and talking together and helping each other in order to master the subject matter.

In this article we examine observations from mathematics lessons in grade 7 . The children are between ten and thirteen years of age, most of them are eleven (mean age 11.07). There are 22 children in this class: 5 students are native Dutch (one of them has a Dutch father and a Czech mother, but she is considered to be Dutch by the teachers), and 17 students have other backgrounds: 12 Moroccan, 3 Turkish, 1 from Yugoslavia, and 1 from Ghana. The Moroccan and Turkish students are second generation children: their parents are immigrants, but the children themselves were born in the Netherlands. The children from Yugoslavia and Ghana are from families that recently came to the Netherlands as refugees.

In the classroom the children are seated in groups of four or five, and each student has his or her own place. The arrangement of the tables is such that children can talk and work together easily. According to the teacher's clarification, the groups have been put together in such a way that there is a combination of good collaboration and order and quiet. Table 1 shows the composition of the groups (see Table 1). The names in the Table are pseudonyms.

\section{Table 1}

The composition of the groups

\begin{tabular}{|c|c|c|c|c|}
\hline Group 1 & Group 2 & Group 3 & Group 4 & Group 5 \\
\hline Feliz (Turkish girl) & Ferit (Moroccan boy) & Annelies (Dutch girl) & Abdel (Moroccan boy) & Chantal (Dutch girl) \\
\hline Samira (Moroccan girl) & Fouzia (Moroccan girl) & Berend (Dutch boy) & Fahd (Turkish boy) & Daniëlle (Dutch/Czech girl) \\
\hline Assad (Moroccan boy) & Ilham (Moroccan girl) & Goran (Yugoslavian boy) & Ikram (Moroccan girl) & Farouk (Moroccan boy) \\
\hline Hassan (Moroccan boy) & Zakaria (Moroccan boy) & Maktoub (Moroccan boy) & $\begin{array}{l}\text { Françoise (Ghanaian girl) } \\
\text { Lonneke (Dutch girl) }\end{array}$ & $\begin{array}{l}\text { Mimoun (Moroccan boy) } \\
\text { Yalcin (Turkish boy) }\end{array}$ \\
\hline
\end{tabular}

The common procedure in this classroom is that the teacher explains a subject to the whole class, and then tells the children to do their work, - for instance, to solve tasks from their textbooks, and to do it in collaboration with the other students in their group. She tells the children to "think together" and "do the assignment together". Moreover, the students are told to solve the problems in a logical way; that means in a way that is mathematically sound. Children who have understood the problem are supposed to help other children and to explain 
their solutions to them. It is not sufficient if one child tells others that their solution is not right. The teacher makes it clear that the children should contribute to their classmates' understanding by listening to them, explaining their own approach, asking questions, and discussing solutions. During the collaboration phase, the teacher walks around the classroom, occasionally helping students and asking them to explain to her what they are doing.

The analysis is based on audio and video recordings of children's conversations during the lessons. Since each mathematics lesson takes approximately one hour, our analysis covers twenty hours of recordings (five groups with four lessons of one hour). A video camera was placed in one corner of the classroom to give an overview of what happened during the lesson. The children's conversations were recorded with small tape recorders placed on one of the tables in each group. We transcribed the audio recordings of these lessons and used these transcripts as the main source for our analyses. The subjects in these mathematics lessons were the calculation of area and volume, the transformation of measures of area and volume, co-ordinates and working with a calculator.

We read the transcripts and selected all situations in which the children discussed the meaning of words or expressions or in which one or more children expressed unfamiliarity with a term or expression. We also included situations in which children spontaneously corrected each other when one student clearly misunderstood a term. Next, we classified the selected situations according to four patterns, corresponding to different approaches to solving problems of unfamiliar words. In addition, we selected situations in which the teacher spoke about the meaning of words in front of the classroom.

\section{Results}

Before presenting the observations of the conversations in the groups, we want to report that, in the observed lessons, the teacher twice helped the students to comprehend the meaning of difficult words. One assignment involved planting trees in three plots of woodland. In the textbook, these plots are described as A, B and C and these letters refer to three scale drawings of the three plots. In her introduction, the teacher read the assignment aloud and asked Goran what "a plot of woodland" was, adding that he should look carefully at his book. Goran responded immediately with "a piece of woodland". The teacher reacted with "very good" and repeated Goran's description several times.

In een hoek van de winkel maakt een winkelmeisje een mooie stapel van pakjes roggebrood.

De stapel wordt 6 pakjes hoog in het midden.

De stapel wordt naar beneden toe steeds breder.

Bovenaan ziet de stapel er uit als op de tekening.

A. Hoeveel pakjes roggebrood liggen er op de stapel?

B. Als één pakje f I,98 kost, wat kost dan de hele stapel?

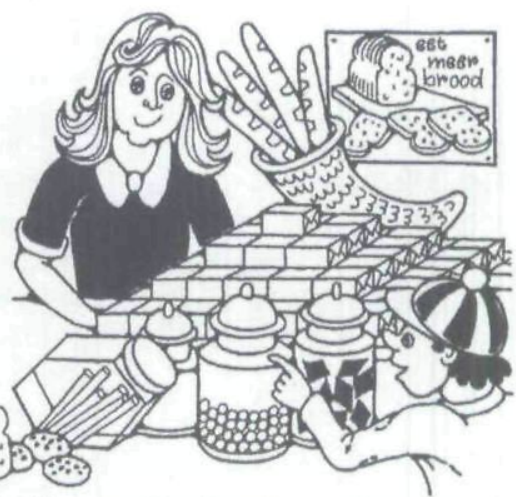

Figure 1. "In a corner of the shop a shop assistant is making a pile of packets of rye bread. The pile is six packets high in the centre. The pile gets wider and wider as you move further down. The pile looks just like you can see it in the picture. A. How many packets of rye bread are in the pile? B. If one packet costs one guilder ninety eight, what does the whole pile cost?" Reproduced (with permission) from De Wereld in Getallen, Rekenboek 5b. Den Bosch, Malmberg (n.d.), page 164. 
The second situation was the assignment shown in Figure 1. The assignment concerns a baker's shop and refers to the pile of packets of rye bread, which the shop assistant has made. In reading the assignment aloud, the teacher held up the textbook and pointed to the pile of rye bread packets on the right of the drawing. These were the only situations in the observed lessons in which the meaning of terms was explained. The teacher did not suggest that part of the students' collaboration could consist of helping each other to understand unfamiliar or difficult words. Neither did she mention a special role for the Dutch students with respect to language difficulties.

Table 2

Words that were discussed in the groups and patterns of clarification

\begin{tabular}{|c|c|c|c|c|c|}
\hline Word & Group & Ignored & Shown by gesture & Explained & Discussed \\
\hline Pavement & 5 & & & & $\mathrm{X}$ \\
\hline Carpet tile & 1 & & $\mathrm{X}$ & & \\
\hline Carpet tile & 2 & & $\mathrm{X}$ & $\mathrm{X}$ & \\
\hline Carpet tile & 4 & & $\mathrm{X}$ & & \\
\hline Carpet tile & 5 & & & & $\mathrm{X}$ \\
\hline Phone book & 2 & & & & $\mathrm{X}$ \\
\hline Phone book & 3 & $\mathrm{X}$ & & & \\
\hline Phone book & 4 & $\mathrm{X}$ & & & \\
\hline Phone book & 5 & & $\mathrm{x}$ & & \\
\hline Pin point & 5 & & & & $\mathrm{X}$ \\
\hline Rye bread & 2 & & $\mathrm{X}$ & & \\
\hline Rye bread & 3 & & $\mathrm{X}$ & & \\
\hline Rye bread & 4 & & $\mathrm{x}$ & & \\
\hline Plot & 1 & $\mathrm{X}$ & & & \\
\hline Plot & 5 & $\mathrm{X}$ & & & \\
\hline Beech tree & 3 & $\mathrm{X}$ & & & \\
\hline Volume & 4 & & & $\mathrm{X}$ & \\
\hline Volume & 5 & & & $\mathrm{X}$ & \\
\hline
\end{tabular}

Table 2 gives an overview of our observations and analysis. It shows the words which were talked about, the groups in which the difficulties were expressed and the pattern of clarification which we observed. We found 18 situations, all of which, except two, involve everyday words. Two situations related to a mathematical term: 'volume'. We grouped the observations into four patterns of clarification.

We will illustrate the four patterns of clarification and give examples of the assignments and of the way the students clarified or attempted to clarify the word meaning during their collaboration.

The first pattern is that questions about the meaning of words are ignored. Somebody asks a question but nobody replies and that is the end of it. Ignoring questions about word meaning was found in 5 of the 18 cases. Generally, this pattern occurs when a question about the meaning of a word is put precisely at the moment when other children are very much involved in working out the solution to an assignment.

\section{Excerpt 1 (Ignoring) Group 4}

The assignment is: The area of a phone book is about $8 \mathrm{dm}^{2}$. True or not true?

1. Fahd: [reads] The area of a phone book is about eight decimetres.

2. Abdel: Not true, is not true, not true.

3. Françoise: A phone book is always a pocket book, isn't it?

4. Ikram: [addressing Abdel] How come? How do you know? 
Ikram, in line 4, reacts to Abdel's contribution and Françoise's question goes unnoticed and is ignored.

The second pattern consists of showing by gestures. This pattern is illustrated in Excerpt 2 . Children indicate the area of a carpet tile with their hands.

\section{Excerpt 2 (Showing) Group 1}

The assignment is: The area of a carpet tile is $25 \ldots$ (The children have to complete this sentence by finding the right unit).

1. Hassan: Now it's my turn to read.

2. Feliz: The area of a carpet tile is twenty-five.

[...]

3. Feliz: Twenty-five. The area of a carpet tile is twenty-five?

4. Assad: I don't even know what a carpet tile is.

5. Samira: [making a gesture] I know, it's about this.

6. Feliz: [making a gesture] No, the tile is about this.

7. Assad: [making a gesture]A carpet tile is this small.

8. Samira: I know that.

9. Assad: [addressing Samira, making a gesture] Why do you say: this big?

[...]

10. Samira: [making a gesture] A carpet tile is about this.

During this conversation, the children illustrate their verbal statements with gestures. They all use basically the same gesture, moving both hands apart on a horizontal line, for showing how big a carpet tile is. Samira (line 5) makes a wide gesture, which Feliz criticizes by making a much smaller gesture in line 6 . Assad's hands, in line 7, estimate the width of a carpet tile as being even smaller. Later (in line 9), he mockingly addresses Samira by imitating her wide gesture. However, in line 10, Samira sticks to her estimate of the width of a carpet tile.

Another form of showing is evoked by the assignment on the rye bread (Figure 1). Here the students point to the picture in reaction to the question: what is rye bread? In none of the cases is the meaning of rye bread explicated. In all cases one of the students points to part of the picture in order to make clear to the other students what it is the assignment refers to.

The third pattern is explanation: one of the children explains the meaning of the word to others. In Excerpt 3 there is a combination of explanation and showing by gesture.

\section{Excerpt 3 (Explanation and Showing) Group 2}

The same assignment as in Excerpt 2.

1. Fouzia: [reads] The area of a carpet tile is twenty-five, eh, metres.

2. Ilham: Carpet tile? What is that?

3. Zakaria: What? Yes.

4. Fouzia: Don't you know what that is?

[...]

5. Fouzia: Don't you know what a carpet tile is?

6. Boy: Is it a carpet in squares?

7. Fouzia: Do you know what it is? Do you know what it is?

8. Boy: No.

9. Fouzia: It serves you right. They seem to think that I am going to explain! 
10. Boy: Square carpet. Square carpet.

11. Fouzia: [laughing] No.

12. Ilham: What is it then?

13. Boy: What is it?

14. Fouzia: No, it is square, like this [making a gesture], just like a carpet, it is also soft, but then it is made of stone.

15. Boy: [?]

16. Fouzia: A carpet tile.

17. Zakaria: Is centimetres. Twenty-five centimetres.

18. Fouzia: Yes, twenty-five. No, metres.

Reacting to Ilham's question in line 2, Fouzia, first boasts of her knowledge of the meaning of the word 'carpet tile' (lines 4, 5, 7 and 9), and she laughingly rejects her fellow student's explanation of a carpet tile as "square carpet" (lines 10 and 11). However, it is clear that in the end Fouzia does not give the right description herself (in line 14). During her explanation (in line 14) she accompanies her description with a hand gesture which show the width of a carpet tile. It is probably on the basis of her gesture that the other students proceed to solve the task.

The other two cases of explanations concern the concept of volume. They are very brief interactions, in which one of the students explains the concept to other children (Excerpts 4 and 5).

\section{Excerpt 4 (Explanation) Group 4}

The assignment consists of the calculation of the volume of a box of given dimensions.

Ikram: What do they mean by volume?

Fahd: $\quad$ Everything, Length, width and height.

Lonneke: You should add them up.

Abdel: That is very easy.

\section{Excerpt 5 (Explanation) Group 5}

The same assignment as in Excerpt 4.

Farouk: What is volume?

Danielle: Look, length times width times height.

The fourth pattern involves discussion about meaning. It occurs in four cases. This is a pattern in which several students propose and argue for different meanings of a difficult word. One example is the meaning of pin point. The difficulty is expressed by Danielle (line 3 ).

\section{Excerpt 6 (Discussion) Group 5}

The assignment is: The area of the point of a pin is $2 \mathrm{~mm}^{2}$. True or not true?

1. Chantal: The area of the point of a pin is two millimetres.

2. Farouk: Is true!

3. Danielle: What is the point of a pin?

4. Chantal: The point of a pin. A pin. Has miss got a pin anywhere?

5. Chantal: The area, yes. OK.

6. Danielle: Yes, that is true.

7. Chantal: The area of a pin, a thin pin. 
8. Danielle: Maybe one.

9. Mimoun: Tss. Even thinner.

10. Farouk: Hey, a pin is long, like this.

11. Chantal: Yes, but how thin it is.

12. Farouk: Wait. That means: not true.

13. ? Who has a point of a pin?

14. Chantal: It is as big as the point of my pencil.

15. Danielle: [Finding a pin]Yes, that is a pin. Give it to me. I think that it is not even one millimetre.

16. Chantal: Yeees.

17. Danielle: Not even that. [...]

18. Chantal: There are thicker pins.

19. Farouk: Yes.

20. Mimoun: Yes, but they are talking about the point.

21. ? Where?

22. Mimoun: The point.

23. Danielle: The area of the point.

24. Chantal: It could be two millimetres.<smiles>[C]1[CH]C=C1</smiles>

25. Mimoun: I've got it: it is not true.

Excerpt 6 shows that children come up with several descriptions of what a pin point is, they criticize each other about the suggested meanings and try to find something like a consensus. Danielle (line 15) succeeds in producing a pin, she probably gets it from a student in another group. Despite the students' attempts to reach an agreement, in the end Chantal and Mimoun disagree (see lines 24 and 25).

In group 2 , with only minority children, there is an interesting discussion about the question of whether a telephone book is the same as a notebook used for noting down telephone numbers. During their discussion, the children mention various alternative terms: telephone book, phone book, address book, notebook, directory. The discussion ends suddenly, and it is not clear whether a common understanding about the meaning of 'telephone book' has been reached.

The discussion about the 'carpet tile' in group 5 leads to a fierce debate in which Mimoun and Chantal oppose Danielle's opinion that a carpet tile is $25 \mathrm{~cm}^{2}$. Chantal argues that what Danielle talks about cannot possibly be a carpet tile. Mimoun tells Danielle that such a small tile must be part of the carpet in a Barbie doll's house and Chantal advises Danielle to measure the carpet tiles in the hallway of her house.

The word 'pavement' (in an assignment about the area of a 'paving stone') also leads to a discussion in group 5, in which students use the terms 'pathway' and 'footpath' as alternatives. In their enthusiasm the children forget that the assignments concerns the area of a paving stone, and they speculate about the areas of a pathway and a footpath. In the end, the teacher intervenes and reminds them that the assignment is about paving stones.

\section{Discussion}

We discuss our findings by relating them to the three levels of means (Cole, 1996) that mediated the conversations in the classroom: (1) the symbolic and material tools used by the students to clarify difficulties with unfamiliar words, (2) the norms for social interaction in the classroom, and (3) the mathematical discourse. 


\section{Symbolic and material tools in the clarification of word meaning}

Our observations become important against the background of Van den Boer's findings that minority students who have a mother tongue other than Dutch do not ask for clarification of word meaning during teacher fronted classroom instruction. In the classroom that we observed, where students work together on math assignments, they do raise problems with word meanings. However, students' conversations about word meaning are restricted to their collaborative group activities. On the basis of Table 2 it cannot be concluded that words that did not provoke questions about their meaning are known to all students. For instance, it is improbable that words such 'plot of woodland' or 'pavement' are familiar to all students in the groups where the terms were not talked about. The table possibly shows the tip of an iceberg.

The students used a variety of symbolic and material tools to clarify the meaning of unfamiliar or difficult words: the Dutch language, gestures, the assignments and drawings in the textbook, and also a real pin. These tools were used as mediational means in the creation of common understanding. Migrant children did not use languages other than the Dutch language in the conversations about word meaning. Dirim (1998), in a study of German/Turkish bilingual children in a classroom at a German primary school, found that these children helped each other to comprehend words and expressions in assignments. This researcher gives examples of children who translated terms which were unfamiliar to some of them into Turkish. In our classroom we occasionally found instances of children talking among themselves in their first language. However, this did not occur during the conversations about word meaning. We did not see meaning clarification in languages other than Dutch, not even in group 2 with only Moroccan children with a Berber background.

\section{Social norms in the classroom and the clarification of word meaning}

The conversations are dependent on the special character of the school with its practice of peer collaboration. Helping each other by clarifying the meaning of terms is part of the collaboration to which the students at this school have been accustomed since the first grade. The social norms for collaboration which are a consequence of the school's philosophy about how children should learn, and the students' experience with collaboration mediate the conversations about word meaning. We can contrast our observations with a Dutch study in the first grade of two multicultural secondary schools (Elbers, Hajer, Jonkers, \& Prenger, 2005). During 23 hours of math instruction in these schools, Elbers et al., did not observe any group work or peer collaboration and did not find a single case of students talking about unfamiliar words. This finding does not imply that students in classrooms with predominantly teacher fronted teaching never help each other to understand the meaning of words or expressions. However, in a traditional classroom there is less opportunity for verbal interactions than in a classroom where students learn by collaboration in small groups (Rulon \& McCreary, 1986; Damhuis, 2000). Stimulating collaboration between students, therefore, is not only a didactic tool to promote learning (Cohen, 1994), but it is also a way of helping migrant students to improve their mastery of the language of instruction.

Conversations about word meaning occur in all groups. In groups 1 and 2, with only migrant children, the expertise of native speakers of Dutch is not available. We do not know if some migrant children have a better command of the Dutch language than others and are therefore addressed to explain difficult words. It must be added that not all conversations in the groups with only migrant children led to the right clarification of meaning (see for instance Excerpt 3, in which Fouzia's clarification of a carpet tile is unsatisfactory but the children can use her accompanying gestures, which show how big a carpet tile is, to solve the assignment). In groups 3, 4 and 5, with a combination of native Dutch and migrant children, the Dutch children are addressed by migrant children to clarify the meaning of words, with the possible exception of Excerpt 5 when Danielle, who has a Dutch father and a Czech mother, puts the question what a 'point of a pin' means. In these groups, there is no instance of clarification of meaning given by a migrant student. There is a clear division of roles: migrant children ask, 
Dutch children answer. The Dutch children are considered competent speakers of the Dutch language by their class-mates, they are addressed as language experts. The Dutch children take this ascribed role for granted. This division of roles in which members of the dominant culture take the position of cultural and linguistic specialists has been found frequently in studies of intercultural communication (e.g., Koole \& Ten Thije, 1994; Day, 1998).

The minority students' opportunities for participation were increased by the collaborative activities: their non-fluent command of Dutch was repaired and overcome by the Dutch students' assistance. However, as a result, minority students often depend on their Dutch classmates' help for being able to solve the mathematical problems. The situation in the present classroom with children with a total of seven different languages is decidedly more complicated than the bilingual classroom Moschkovich (2002) reports on. There is every reason to expand the minority children's command of the Dutch language in order to make them more independent of the Dutch children's assistance (cf. Elbers \& Haan, 2004).

The interactions about word meaning revealed four patterns: 'negation', 'showing by gesture', 'explanation' and 'discussion'. The 'discussion' pattern is especially interesting. During discussions the meaning of a word is negotiated with arguments which support various interpretations or which refer to different meanings or connotations. We observed four instances of the 'discussion' pattern, three of them in group 5. In order to contrast the differences between 'discussion' on the one hand, and 'explanation' on the other hand, Lotman's distinction between conversations with a dialogic and with a univocal character is illuminating (cf. Wertsch, 1998; Damhuis, 2000). The function of univocal communication is to convey information; this kind of talk leads to passive understanding. Dialogic talk, in contrast, is directed at the joint construction of new meanings. In the 'discussion' pattern, talk functions at a dialogic level, whereas interaction in the 'explanation' pattern is univocal. The third pattern, 'showing by gesture', is somehow in between the univocal and dialogic patterns. Students do react to each other, such as in Excerpt 2, in which students use gestures for proposing different interpretations of the width of a carpet tile. However, they merely demonstrate their opinions without supporting arguments. Since recent approaches to second language learning attach special value to the social negotiation of meaning, we conclude that the 'discussion' pattern is probably the most productive for learning Dutch.

The importance of the 'discussion' pattern goes beyond the issue of language learning. Since the various interpretations of the meaning of a word may lead to different solutions of the assignment, the discussions are also valuable for learning mathematics. It is a pity that in three out of four cases the discussion ended without a common understanding on the part of the students. From a didactic point of view on collaborative classrooms, teachers could try to improve the quality of the collaboration by encouraging students to use the 'discussion' pattern. Stimulating dialogic talk would be fruitful both for children's language acquisition and the learning of mathematics. One suggestion is that students should be stimulated to end their conversations only after they have constructed a solution that everybody can agree to. The demand for a consensus would prevent negotiations of meaning from being terminated prematurely, so that no children are excluded from the dialogic process (Mercer, 1995).

\section{The mathematical discourse and the clarification of word meaning}

How relevant is the fact that the conversations about word meanings occurred in mathematics lessons? In other words: what was the influence of the socio-mathematics norms on the conversations? Students' conversations about unfamiliar words show that the clarification of meaning was being mathematized. Mathematics demands mathematization, i.e., the transformation of an everyday situation into a mathematical problem. The normal way of proceeding (or rather the way desired by the teacher) can be reconstructed as follows: the assignment introduces an everyday situation. On the basis of an understanding of this situation, the student highlights specific elements or aspects of the situation that are suitable for mathematical operations. For instance, in an assignment in which students have to calculate the number of packets of rye bread in a large pile, the packets of rye bread are reduced to 
objects which can be put together in a pile and counted. After mathematization, it is no longer relevant whether they are packets of rye bread or something else. It could have been books or bricks. The result of a process of mathematization is that an everyday situation has been transformed into a mathematical problem. First, there is the everyday meaning, and then the mathematical meaning.

However, what we see in most conversations is that the everyday meaning is skipped over and the conversation is focused directly on the second, mathematical meaning. The children in groups 2, 3 and 4 do not explain the meaning of rye bread. Instead, they point to the part of the drawing that shows the pile of packets of rye bread. They give as much information as is needed to solve the assignment and nothing more. Nowhere is the meaning of rye bread clarified with verbal means. This observation also holds for the unclear terms which are ignored. In the cases of beech tree and plot of woodland, the assignment is accompanied by a drawing, which leaves little room for interpreting these terms differently from what is asked for by the assignment. If students know that we are dealing with a tree why should they bother to find out the difference between a beech tree and other types of trees?

The words occurring in the 'discussion' pattern are exceptions only at first sight. Various aspects of a pin are discussed in Excerpt 5: its length, its thickness, etc. But everyday aspects of a pin are not mentioned at all: the use of pins for fastening something, or the fact that a pin is sharp and can prick. Fouzia's attempt to clarify the everyday meaning of a carpet tile in Excerpt 3 is unsuccessful and her gestures for showing the area of a carpet tile are more useful than her verbal explanation. The discussions of the meaning of a telephone book in group 2 and the discussion about the pavement in group 5 come closest to clarifying the everyday meaning of these terms. In these cases, the unfamiliar words are clarified by the use of various synonyms.

Even the teacher shows that the clarification of meaning is directed at the mathematical aspects of the assignment and not at an everyday understanding (Excerpt 7). The teacher is asked for help in group 1. Here, there were no problems to find the pile of packets of rye bread, but the students did not know how to approach the task. The teacher, in response, explained the assignment:

\section{Excerpt 7 Group 1}

Samira: Miss, I don't know exactly how to do it.

Teacher: This pile with packets of butter, how high is the pile. (...) There is one packet of butter on top. And then they make another layer around it. Until you have six layers. In the first layer, how many packets of butter is that?

The teacher refers to packets of butter instead of packets of rye bread. In doing so, she makes it clear implicitly that the precise meaning of packets of rye bread is not important. It does not matter whether these are packets of rye bread or packets of butter.

Questions such as 'What is rye bread?' appear, at first sight, to be everyday questions, but in the groups these questions are interpreted not as questions to clarify the meaning of rye bread, but as a request to explain which part or aspect of rye bread is relevant in the context of the mathematical task. This means that, in these conversations, there are not two phases, one in which the everyday meaning of a word is clarified, a second in which the children do the mathematics assignment. The request for clarification is made subordinate to the mathematical discourse and integrated into it. The functional, 'mathematized' clarification of meaning allows students to work on the assignments, even if they do not understand the everyday meaning of the terms.

\section{Conclusion}

While working collaboratively at their math assignments students had to solve difficulties with unfamiliar Dutch words. They used a variety of symbolic and material tools to construct common understanding of words and expressions. Our study reveals that the issue of learning 
vocabulary in the context of classroom activities is not an isolated phenomenon. Discussing vocabulary is interwoven with both the social norms and the mathematical discourse in the classroom. The social norms of collaboration demanded that the children solve their problems together. Talking together about the meaning of words was made possible and encouraged by the students' familiarity and experience with collaboration. It is not obvious that students deal with their language problems in this way, as our comparison with other, more traditional classrooms showed. It is also impossible to separate vocabulary from the mathematical discourse and the socio-mathematical norms implied by the mathematical discourse. The students did not treat the difficulties as mere problems of vocabulary, but made them part of the process of mathematical exploration. They used the mathematical discourse as a mediational tool for constructing a particular, mathematical, meaning of the words. Therefore, both the social norms and the mathematical discourse served as mediational tools for approaching and solving language problems.

\section{References}

C.B.S. (2004). Jaarboek onderwijs in cijfers 2003-2004 [Annual report on education in figures 2003-2004]. Deventer, the Netherlands: Kluwer.

Cohen, E. (1994). Designing groupwork. Strategies for the heterogeneous classroom. New York: Teachers College Press.

Coady, J. (1997), L2 vocabulary acquisition. A synthesis of the research. In J. Coady \& T. Huckin (Eds.), Second language vocabulary acquisition. A rationale for pedagogy (pp. 273-290). Cambridge, MA: Cambridge University Press.

Cole, M. (1996). Cultural psychology. A once and future discipline. Cambridge, MA: Belknap Press.

Dagevos, J., Gijsberts, M., \& Van Praag, C. (2003). Rapportage minderheden 2003. Onderwijs, arbeid en sociaalculturele integratie [Minorities report 2003. Education, labour and sociocultural integration]. Den Haag: Sociaal en Cultureel Planbureau.

Damhuis, R. (2000). A different teacher role in language arts education. Interaction in a small circle with teacher. In J.K. Hall \& L.S. Verplaetse (Eds.), Second and foreign language learning through classroom interaction (pp. 243-264). Mahwah, NJ: Erlbaum.

Day, D. (1998). Being ascribed, and resisting, membership of an ethnic group. In C. Antaki \& W. Widdicombe (Eds.), Identities in talk (pp. 151-170). London: Sage.

De la Fuente, M.J. (2002). Negotiation and oral acquisition of L2 vocabulary. The roles of input and output in the receptive and productive acquisition of words. Studies in Second Language Acquisition, 24, 81-112.

Dirim, I. (1998). "Var mi lan Marmelade?" Türkisch-deutscher Sprachkontakt in einer Grundschulklasse ["Var mi lan Marmelade?" Turkish-German language contact in a primary school classroom]. Münster: Waxmann.

Elbers, E., \& Haan, M. de (2004). Dialogic learning in the multi-ethnic classroom. Cultural resources and modes of collaboration. In J. van der Linden \& P. Renshaw (Eds.), Dialogical perspectives on learning (pp. 17-43). Dordrecht: Kluwer.

Elbers, E., Hajer, M., Jonkers, J., \& Prenger, J. (2005). Instructive dialogues: Participation in dyadic interactions in multicultural classrooms. In R.M. Maier \& W. Herrlitz (Eds.), Dialogues in and around multicultural schools. Tübingen, Germany: Max Niemeyer Verlag.

Freudenthal, H. (1991). Revisiting mathematics education. Dordrecht: Kluwer.

Haan, M. de, \& Elbers, E. (in press). Minority status and culture: Local constructions of diversity in a classroom in the Netherlands. Intercultural Education.

Koole, T., \& Ten Thije, J. (1994). The construction of intercultural discourse. Team discussions of educational advisers. Utrecht: Utrecht studies in language and communication.

Lee, O., \& Fradd, S. (1996). Interactional patterns of linguistically diverse students and teachers. Insights for promoting science learning. Linguistics and Education, 8, 269-297. 
Long, M. (1996). The role of linguistic environment in second language acquisition. In W. Ritchie \& T. Bhatia (Eds.), Handbook of second language acquisition (pp. 413-468). San Diego: Academic Press.

Mackey, A., Oliver, R., \& Leeman, J. (2003). Interactional input and the incorporation of feedback: An exploration of NS-NNS and NNS-NNS adult and child dyads. Language Learning. 53, 35-66.

Mercer, N. (1995). The guided construction of knowledge. Talk amongst teachers and learners. Clevedon: Multilingual Matters.

Moschkovich, J. (2002). A situated and sociocultural perspective on bilingual mathematical learners. Mathematical Thinking and Learning. 4, 189-212.

Nunes, T, Schliemann, A., \& Carraher, D. (1993). Street mathematics and school mathematics. Cambridge: Cambridge University Press.

Porter, P. (1986). How learners talk to each other. Input and interaction in task-centered discussions. In R. Day (Ed.), Talking to learn. Conversation in second language acquisition (pp. 200-222). Rowley, MA: Newbury House.

Rulon, K., \& McCreary, J. (1986). Negotiation of content: Teacher fronted and small group interaction. In R. Day (Ed.), Talking to learn. Conversation in second language acquisition (pp. 182-199). Rowley, MA: Newbury House.

Swain, M. (2000). The output hypothesis and beyond: Mediating acquisition through collaborative dialogue. In J.M. Lantolf (Ed.), Sociocultural theory and second language acquisition (pp. 97-114). Oxford: Oxford University Press.

Tesser, P., \& Iedema, J. (2001). Rapportage minderheden 2001. Vorderingen op school [Minorities report 2001. Progress at school]. Den Haag: Sociaal en Cultureel Planbureau.

Van de Molengraaf, G. (Ed.). (n.d.). De wereld in getallen. Rekenboek $5 b$ [The world in figures. Textbook 5b]. Den Bosch, the Netherlands: Malmberg.

Van den Boer, C. (2003). Als je begrijpt wat ik bedoel. Een zoektocht naar verklaringen voor achterblijvende prestaties van allochtone leerlingen in het wiskundeonderwijs [If you see what I mean. A quest for an explanation of the lower achievement levels of minority students in mathematics education]. Utrecht, CD-B Press.

Van den Branden, K. (1997). Effects of negotiation on language learners' output. Language Learning, 47, 589-636.

Wartofsky, M. (1979). Models. Representation and the scientific understanding. Dordrecht, the Netherlands: Reidel.

Wertsch, J. (1998). Mind as action. New York: Oxford University Press.

Yackel, E., \& Cobb, P. (1996). Sociomathematical norms, argumentation, and autonomy in mathematics. Journal for Research in Mathematics Education, 27(4), 458-477.

Dans cet article, nous examinons la construction de la signification des mots par des élèves pendant des activités de groupe dans une classe multiculturelle d'une école primaire hollandaise. L'analyse se base sur des enregistrements de conversations entre élèves dans des groupes de quatre ou cinq, pendant les leçons de mathématiques. Des difficultés avec des termes spécifiques et des expressions apparaissent fréquemment pendant le travail en groupe. Les élèves pouvaient facilement questionner entre eux la signification des mots difficiles lors des exercices en groupe auxquels ils étaient habitués. Dans les groupes où il y avait des élèves hollandais et des élèves minoritaires, ces derniers s'adressaient à leurs camarades hollandais en tant qu'experts du langage. Les groupes composés seulement d'élèves minoritaires parlaient aussi des difficultés de langage. Les conversations sur la signification des mots ont révélé quatre types de réactions: (1) ignorer une question sur le sens d'un mot, (2) montrer le sens avec des gestes, (3) expliquer ou (4) discuter le sens des mots. Dans aucun des cas les problèmes de langage ont été traités en faisant référence au sens quotidien du mot. Au contraire, les conversations étaient centrées directement sur la signification particulière que le mot avait dans le contexte du cours de mathématiques. Cela signifie que les élèves utilisaient le discours mathématique comme outil médiateur pour construire le sens mathématique des mots. 
Key words: Linguistic diversity, Mediation, Multicultural classroom, Peer collaboration, Socio-mathematical norms.

Received: June 2004

Revision received: Novembre 2004

Ed Elbers. Utrecht University, Faculty of Social Sciences, P.O. Box 80140, 3508 TC Utrecht, The Netherlands; Tel.: +31 30 2531408; Fax: +31 30 2534733; E-mail: E.Elbers@fss.uu.nl

Current theme of research:

Learning and interaction in multicultural classrooms. Communication in educational settings. Collaborative learning.

Most relevant publications in the field of Psychology of Education:

Elbers, E. (2003). Classroom interaction as reflection. Learning and teaching in a community of inquiry. Educational Studies in Mathematics, 54, 77-99.

Elbers, E. (2004). Conversational asymmetry and the child's perspective in developmental and educational studies. International Journal of Disability, Development and Education, 5I(2), 201-215.

Elbers, E., \& Haan, M. de (2004). Dialogic learning in the multi-ethnic classroom. Cultural resources and modes of collaboration. In J. van der Linden \& P. Renshaw (Eds.), Dialogical perspectives on learning, teaching and instruction (pp. 17-43). Dordrecht: Kluwer.

Elbers, E., Hajer, M., Jonkers, M., \& Prenger, J. (2005), Instructive dialogues: Participation in dyadic interactions in multicultural classrooms. In R. Maier \& W. Herrlitz (Eds.), Dialogues in and around multicultural schools (pp. 249-264). Tübingen: Max Niemeyer Verlag.

Elbers, E., Maier, R., Hoekstra, T., \& Hoogsteder, M. (1992). Internalization and adult-child interaction. Learning and Instruction, 2, 101-118.

Mariëtte de Haan. University of Utrecht, Faculty of Social Sciences/ASW, Heidelberglaan 2, 3584 CS Utrecht, The Netherlands; Tel.: 3130 2537735, 3130 2531408; Fax: 3130 2534733; E-mail: M.dehaan@fss.uu.nl

Current theme of research:

Socialization of migrants and cultural change. Collaborative learning. Multi-ethnic classrooms. Ethnicity. Community learning vs. school learning.

Most relevant publications in the field of Psychology of Education:

Haan, M. de (1999). Learning as cultural practice. How children learn in a Mexican Mazahua community. A study on culture and learning. Amsterdam: Thela Thesis.

Haan, M. de (2001). Intersubjectivity in models of learning and teaching: Reflections from a study of teaching and learning in a Mexican Mazahua community. In S. Chaiklin (Ed.), The theory and practice of cultural-historical psychology (pp. 174-199). Aarhus University Press.

Haan, M. de (2002). Distributed cognition and the shared knowledge model of the Mazahua: A cultural approach. Journal of Interactive Learning Research, 13(1), 31-50.

Haan, M. de, \& E. Elbers (in press). Minority status and culture: Local constructions of diversity in a classroom in the Netherlands. Intercultural Education.

Maier, R., \& Haan, M. de (2003). Les dynamiques multiculturelles dans les écoles néerlandaises. Revue Française de Pédagogie, 144, 39-47. 
Copyright of European Journal of Psychology of Education - EJPE is the property of Instituto Superior de Psicologia Aplicada and its content may not be copied or emailed to multiple sites or posted to a listserv without the copyright holder's express written permission. However, users may print, download, or email articles for individual use. 